\title{
Some medicinal plants with antiasthmatic potential: a current status
}

\author{
Dnyaneshwar J Taur ${ }^{1^{*}}$, Ravindra Y Patil ${ }^{2}$ \\ ${ }^{I}$ Department of Pharmacognosy, SVPM's College of Pharmacy, Malegaon (bk), Baramati, Maharashtra, India \\ ${ }^{2}$ Department of Pharmacognosy, PDEA's Shankarrao Ursal College of Pharmaceutical Sciences and Research Center, Kharadi, Pune-411014, \\ Maharashtra, India
}

\section{ARTICLE INFO}

Article history:

Received 3 March 2011

Received in revised form 27 March 2011

Accepted 19 April 2011

Available online 10 May 2011

\section{Keywords:}

Asthma

Antiasthmatic plants

Ayurveda

Herbal medicines

Antiallergic activity

Medicinal property

\section{ABSTRACT}

Asthma is a common disease that is rising in prevalence worldwide with the highest prevalence in industrialized countries. Asthma affect about 300 million people worldwide and it has been estimated that a further 100 million will be affected by 2025. Since the ancient times, plants have been exemplary sources of medicine. Current asthma therapy lack satisfactory success due to adverse effect, hence patients are seeking complementary and alternative medicine to treat their asthma. Ayurveda and other Indian literature mention the use of plants in various human ailments. India has about 45000 plant species and among them several thousand are claimed to possess medicinal properties. Researches conducted in the last few decades on the plants mentioned in ancient literature or used traditionally for asthma have shown antiasthmatic, antihistaminic and antiallergic activity. This review reveals that some plants and their extract have antiasthmatic, antihistaminic, anticholinergic and antiallergic activity.

\section{Introduction}

Asthma is a complex inflammatory disease causes airway narrowing and associated with changes in the levels of eosinophils, mast cells, lymphocytes, cytokines and other inflammatory cell products. It is well known that patients with asthma have high levels of specific $\mathrm{IgE}$ that binds to receptors of mast cells and other inflammatory cells. Interaction between $\mathrm{IgE}$ antibody and antigen results in the activation of a series of inflammatory cellular reactions, including the release of mediators such as histamines, prostaglandins and leukotrienes, which subsequently lead to contraction of airway smooth muscle and bronchoconstriction[1-3]. Asthma is a common disease that is rising in prevalence worldwide, with the highest prevalence in industrialized countries. Asthma affect about 300 million people worldwide and it has been estimated that a further 100 million will be affected by 2025[4, 5]. Since 1970s, the global prevalence, morbidity, mortality, and economic

\footnotetext{
* Corresponding author: Mr. Dnyaneshwar J Taur. Department of Pharmacognosy, SVPM's College of Pharmacy, Malegaon (bk), Tal. Baramati, Dist. Pune.

Tel.: +91-09960464957

E-mail: dnyaneshtaur@gmail.com
}

burden of asthma have increased particular in children[6] .

Medicinal plant used for the treatment of asthma should have anti-inflammatory, immunomodulatory, antihistaminic, smooth-muscle relaxants and allergic activity[7]. According to Ayurveda anti-asthmatic drug should have properties such as anti-kapha and antivata[8]. Antioxidant supplements are effective in reducing bronchoconstriction severity by inhibiting pro-inflammatory events as a result of neutralizing the effects of excess reactive oxygen species and reactive nitrogen species[9]. Current asthma therapy lack satisfactory success due to adverse effect, hence patients are seeking complementary and alternative medicine to treat their asthma [10]. Quercetin is one of the most widely occurring flavonoids ingested in food by humans. Quercetin inhibits mast cell degranulation and subsequent release of histamine.

\section{Adverse effects of current treatments used in asthma[11]}

\subsection{Isoprenaline}

Causes tachycardia. 


\subsection{Salbutamol}

Muscle tremors (dose related), palpitation, restlessness, nervousness, throat irritation and ankle edema.

\subsection{Theophylline}

Convulsions, shock, arrhythmias, increased muscle tone, tachapnoea, (dose dependent) flushing, hypotension, restlessness, tremors, vomiting, palpitation, diuresis, dyspepsia, insomnia etc.

\subsection{Anticholinergics}

Dry mouth, difficulty in swallowing and talking, scarlet rash, photophobia, blurring of near (Atropine and its congeners) vision, palpitation, ataxia, delirium, hallucinations, hypotension, weak and rapid pulse, cardiovascular collapse with respiratory depression, convulsions and coma (in severe poisoning).

\subsection{Ketotifen}

Sedation, dizziness, dry mouth, nausea and weight gain.

\subsection{Corticosteroids}

Cushing's habitus, fragile skin, purple striae, hyperglycemia, muscular weakness, susceptibility to infection, delayed healing of wounds and surgical incisions, peptic ulceration, osteoporosis, glaucoma, growth retardation, psychiatric disturbances, suppression of hypothalamo-pituitary-adrenal (HPA) axis etc.

As a consequence, the search for effective low-risk, non-drug strategies that provide a valuable adjunctive or alternative treatment in asthma management is clinically attractive and relevant. There is much interest in complementary and alternative medicine, and its use in the management and treatment of asthma is growing at a significant rate[10]. Present review describes some plants that have been pharmacologically evaluated for those parameters involved in asthma.

\section{Some traditional plants with antiasthmatic potential}

\subsection{Aerva lanta Linn (Amaranthaceae)}

Aerva lanta (A. lanta) is an erect or prostrate herbaceous common wayside weed which is recognized by its white axillary bunches of small woolly flowers. It is abundant on the plains in the warmer parts of India. Ethanol extract of aerial parts of A. lanata at $100 \mu \mathrm{g} / \mathrm{mL}$ in the isolated goat tracheal chain preparation model and 30 and $60 \mathrm{mg} / \mathrm{kg}$ doses orally in clonidine-induced catalepsy and mast cell degranulation in mice possesses antiasthmatic activity[12].

\subsection{Ageratum conyzoides L.}

Ageratum conyzoides (A. conyzoides) is an erect, herbaceous annual plant from the family Asteraceae (Compositae), native to tropical America, but with a distribution range in tropical and subtropical areas around the world. Hydroalcoholic extract of leaves of $A$. conyzoides at doses of 250, 500 and $1000 \mathrm{mg} / \mathrm{kg}$ shows antihistaminic activity by inhibiting clonidine induced catalepsy in mice[13].

\subsection{Argemone mexicana}

Argemone mexicana (A. mexicana) is common everywhere by road-sides and fields in India. It possesses antiallergic and antistress activity of aqueous extracts of $A$. mexicana stem at dose $50 \mathrm{mg} / \mathrm{kg}$, i.p. using milk-induced leucocytosis and milk-induced eosinophilia[14].

\subsection{Asystasia gangetica T. Adams (Acanthaceae)}

Asystasia gangetica (A. gangetica) is used in many parts of Nigeria for the management of asthma. Akah, et al. evaluated hexane, ethylacetate, and methanol extracts of the leaves of $A$. gangetica for antiasthmatic activity using guinea pig trachea; rat stomach strip; guinea pig ileal preparation and egg albumin-induced acute inflammation. The results indicated that the extracts did not exhibit contractile or relaxant activity in isolated tissue preparations; however, they inhibited the contraction evoked by spasmogens[15].

\subsection{Bacopa monnieri L. (Scrophulariaceae)}

Bacopa monnieri: Samiulla, et al. evaluated petroleum ether, chloroform, methanol and water extracts of $B$. monnieri leaves at doses $10 \mu \mathrm{g} / \mathrm{mL}$ for mast cell stabilizing activity in rats. The result of investigation observed that all the extract significantly inhibits mast cell degranulation[16].

\subsection{Cassia sophera (caesalpiniaceae)}

Cassia sophera (C. sophera) is used in traditionally for treatment of asthma and bronchitis. Chloroform, ethyl acetate and ethanol fractions isolated from ethanol extract of leaves of $C$. sophera possesses significant antiasthmatic activity in carrageenan induced paw edema, histamine induced bronchoconstriction, clonidine and haloperidol induced catalepsy, milk induced leukocytosis, and eosinophilia and passive paw anaphylaxis animal models at doses 250,500 and $750 \mathrm{mg} / \mathrm{kg}$ and this activity may be due to presence of flavonoids[17].

\subsection{Casuarina equisetifolia Linn (Casuarinaceae)}


Casuarina equisetifolia (C. equisetifolia) is evergreen tree; generally attain height up to $50 \mathrm{~m}$, cultivated on Coastal regions from Gujarat to Orissa, some parts of West Bengal and in Andamans. The methanol extract of extracts of wood and bark possesses antihistaminic activity by inhibiting the histamine induced contraction of trachea $(10-80 \mathrm{mcg} / \mathrm{mL})$, clonidine induced catalepsy and mast cell degranulation at doses $100 \mathrm{mg} / \mathrm{kg}[18]$.

\subsection{Clerodendrum Serratum Linn (Verbenaceae)}

Clerodendrum Serratum (C. serratum), known as bharangi in ayurveda, is traditionally useful in treating pain, inflammation, rheumatism, respiratory diseases, and malarial fever. Ethanol extract of roots of $C$. serratum showed antiasthmatic activity using isolated goat tracheal chain preparation, clonidine induced catalepsy; Milk induced leucocytosis and eosinophilia in mice at doses 50,100 and 200 $\mathrm{mg} / \mathrm{kg}[19]$.

\subsection{Cnidium monnieri (Umbelliferae)}

Cnidium monnieri (C. monnieri) in traditional medicine of China has been used for treatment of pain in female genitalia, impotence and suppurative dermatitis as an antipruritogenic agent. Matsuda et al. reported antiallergic activity of ethanol extract and Osthol a chromane isolated from ethanol extract of fruits of $C$. monnieri in passive cutaneous anaphylaxis in rats[20] .

\subsection{Crinum glaucum (Amaryllidaceae)}

Crinum glaucum (C. glaucum) is popular in Yoruba of South West Nigeria. Traditional medicine practitioners reported it as an effective remedy in the relief of cough, asthma and convulsions. The aqueous extract of $C$. glaucum possesses antiallergic activity at dosed $100-400 \mathrm{mg} / \mathrm{kg}$ by reduction in area of dye leakage in passive cutaneous anaphylactic reaction, protecting degranulation of mast cell and histamine induced bronchoconstriction in the guinea pig[21].

\subsection{Curculigo orchioides Gaertn (Amaryllidaceae)}

Curculigo orchioides (C. orchioides) is a tiny herbal plant widely distributed in India, China, Malaya, and Japan. Alcoholic extract of $C$. orchioides rhizomes at doses (100-400 $\mathrm{mg} / \mathrm{kg}$ ) shows mast cell stabilizing and antihistaminic activity on Compound 48/80-induced mast cell degranulation and systemic anaphylaxis[22]. It also inhibited histamineinduced contraction in goat trachea, guinea pig ileum and bronchoconstriction in guinea pigs; egg albumin induced passive paw anaphylaxis in rats; milk induced leucocytosis and eosinophilia; clonidine induced catalepsy in mice[23] .

\subsection{Eclipta alba Linn (Asteraceae)}

The 50\% ethanol extract shows antianaphylactic and antihistaminic activity at doses 250 and $500 \mathrm{mg} / \mathrm{kg}$ on compound 48/80-induced degranulation of mast cell, egg albumin induced passive Cutaneous and paw anaphylaxis; bronchoalveolar lavage (BAL) study on gunea pig trachea; and determination of histamine[24].

\subsection{Euphorbia hirta (Euphorbiaceae)}

Popularly known as asthma weed, Euphorbia hirta is an herbaceous wild plant which grows in the hotter parts of India. Ethanol extract of whole aerial part of the plant at doses (100-1000 mg/kg) shows antihistaminic and antiallergic activity by inhibiting inhibited the passive cutaneous anaphylaxis and paw anaphylaxis reaction; protection of mast cell from degranulation[25].

\subsection{Ficus bengalensis Linn (Moraceae)}

Ficus bengalensisis ( $F$. bengalensis) is a very large tree reaching about $30 \mathrm{~m}$ high and sending down many aerial roots from the branches. Ethyl acetate, ethanol and aqueous extracts as well as fractions isolated from aqueous extract of $F$. bengalensis bark possesses antihistaminic activity by inhibiting clonidine induced catalepsy in mice at dose $50 \mathrm{mg} / \mathrm{kg}$. These activity may be due to presence of flavonoids[26,27].

\subsection{Gakani}

Gakani is a polyherbal drug contains Cenchrus biflorus Roxb. Gramineae Olax subscorpioidea Oliv. (Olacaceae), Piper guineense schum Thonn (Piperaceae), Psorospermum guineense Hochr. (Hypericaceae), Securidaca Iongipedunculata Tresen (Polygalaceae), Syziygium aromaticum (L.) Merr. (Myrtaceae). The antiasthmatic potential of Gakani, a popular herbal drug was investigated using guinea pig tracheal chain; guinea pig ileum preparation; on the rat stomach strip and egg albumin induced hind paw edema. Result indicates that the extract blocked the effects of histamine and isoprenaline on the guinea pig tracheal chain. It shows inhibition contraction of isolated guinea pig ileum and rat stomach strip, caused by histamine and 5-hydroxytryptamine (5-HT). The extract had good anti-inflammatory effect in rats[28] .

\subsection{Hemidesmus indicus R. Br. (Asclepiadaceae)}

Hemidesmus indicus (H. indicus) is a twining shrub commonly found in India. Bhujbal et al. reported antiasthmatic activity of ethanol extract of $H$. indicus roots at doses $25,50,100 \mathrm{mg} / \mathrm{kg}$ using isolated goat tracheal chain preparation, passive paw anaphylaxis in rat and clonidine- 
induced catalepsy in mice[29] .

\subsection{Amburana cearensis (Fabaceae)}

Amburana cearensis (A. cearensis) is a medicinal plant common to the Brazilian Northeastern "caatinga" (savannah), and popularly used in respiratory tract diseases including asthma. The flavonoid isokaempferide isolated from Trunk barks of A. cearensis shows significant relaxation of $\mathrm{KCl}$ induced contraction on guinea pig trachea[30].

\subsection{Plants from Zinziberaceae}

Tewtrakul et al. reported antiallergic activity of ethanol and water extract of some plants of Zinziberaceae family[31].

\subsection{Lepidium sativum Linn (Cruciferae)}

Commonly known as Asaliyo, it is an erect, glabrous annual herb cultivated as a salad plant throughout India. The ethanol extract and ethyl acetate, n-butanol and methanol fractions isolated from ethanol extract inhibit bronchospasm induced by histamine and acetylcholine[32].

\subsection{Mentha spicata $L$}

The four new flavonoids and three new glycosides isolated from ethyl acetate soluble fractions of $M$. spicata leaves shows antihistaminic activity by inhibiting antigen stimulated rat basophile[33].

\subsection{Momordica dioica}

Momordica dioica is climbing creeper plant. Its fruits and leaves are traditionally used as medicinal agent of asthma, leprosy, bronchitis, fever, tridosha. Methanol and aqueous extract of pulp possesses antihistaminic activity by inhibiting clonidine induced catalepsy in mice at dose 50 $\mathrm{mg} / \mathrm{kg}$; this activity may be due to polar constituents[34].

\subsection{Mucuna pruriens}

The L-DOPA isolated from methanol extract of seed possesses antihistaminic activity by inhibiting clonidine induced catalepsy and mast cell degranulation in mice at dose 50, 100 and $200 \mathrm{mg} / \mathrm{kg}[35]$.

\subsection{Myrica esculenta Buch. Ham. (Myricaceae)}

Myrica esculenta is commonly known as Kaiphal. It is used for treatment of asthma and broncititis in ayurvedic system of medicine. Patel et al. reported antiallergic and anti-inflammatory activity of ethanol extract of aerial parts using acetic acid induced vascular permeability and allergic pleurisy in mice methods at doses 75 and $150 \mathrm{mg} /$ $\mathrm{kg}[36]$. Stem bark of this plant possesses bronchodilator and antianaphylactic activity by inhibiting acetylcholine induced bronchospasm in guinea pigs, egg albumin induced anaphylaxis in guinea pigs at dose $75 \mathrm{mg} / \mathrm{kg}$ and by relaxing histamine and acetylcholine induced guinea pig trachea and ileum[37].

\subsection{Nyctanthes arbortristis}

It is used traditionally in the treatment of asthma. The petroleum ether extract shows antihistaminic activity by inhibiting clonidine-induced catalepsy in mice at dose 50 $\mathrm{mg} / \mathrm{kg}[38]$.

\subsection{Olea europea (Oleaceae)}

It is a small evergreen tree, from 12 to 20 feet high, with hoary, rigid branches, and a grayish bark. Aqueous extract of ripe olives possesses antiasthmatic activity by inhibiting clonidine induced peritoneal mast cell degranulation in rats and catalepsy in mice at doses 4 and $8 \mathrm{mg} / \mathrm{kg}$ and also by protecting histamine induced contraction of goat trachea and guinea pig ileum at concentration of $100 \mu \mathrm{g} / \mathrm{mL}[39]$.

\subsection{Phymatodes scolopendria (Burm.) Ching (Polypodiaceae)}

Phymatodes scolopendria is a crawling fern growing in the sandy areas of the East coast of Madagascar. Ramanitrahasimbola et al. reported bronchodilator activity of 1,2-benzopyrone (coumarin) isolated from ethanol extract of aerial parts by inhibiting histamine or carbachol precontracted guinea pig trachea[40].

\subsection{Piper betel Linn}

Piper betel is traditionally used to to cure cough, cold, pruritis, asthma and rheumatism. Ethanol and aqueous extract of leaves at doses 100 and $200 \mathrm{mg} / \mathrm{kg}$ possesses antiasthmactic activity on histamine induced bronchoconstriction in guinea pig and histamine induced dose dependent contraction of guinea pig tracheal chain and isolated guinea pig ileum preparation[41].

\subsection{Striga orobanchioides Benth (Scrophulariaceae)}

Striga orobanchioides is a parasitic plant, lives on the roots of various plants. Ethanol and aqueous extracts of whole plant shows antihistaminic and mast cell stabilizing activity by inhibiting histamine-induced contractions of the guineapig ileum at the concentration $2.5-25 \mu \mathrm{g} / \mathrm{mL}$ in a doserelated manner and inhibiting degranulation of mast cells at dose 100 and $200 \mathrm{mg} / \mathrm{kg}[42-49]$.

\subsection{Sphaeranthus indicus Kurz (Asteraceae)}


Sphaeranthus indicus is a medicinally important plant used as folk medicine. The ethanol extract at the doses of $150,300 \mathrm{mg} / \mathrm{kg}$ and its ethyl acetate extract at the dose of 100 , $150 \mathrm{mg} / \mathrm{kg}$ and $300 \mathrm{mg} / \mathrm{kg}$ showed slightly better protection against sheep serum and Compound 48/80-induced mast cell degranulatiuon than the standard drug ketotifen[50].

\subsection{Cynodon dactylon (Poaceae)}

Cynodon dactylon is one of the most commonly occurring perennial grass throughout India, commonly known as Dhub. The petroleum ether, chloroform and methanol extracts of whole plant and fractions isolated from chloroform extract possess antianaphylactic activity but fractions isolated possesses more potent activity at doses 10, 25, 50 and $100 \mathrm{mg} /$ kg using compound 48/80-induced mast cell degranulation, determination of level of nitric acid in serum, compound 48/80-induced anaphylaxis[51].

\section{Conclusion}

Almost 70 percent of the prescription and OTC (Over the Counter) medicines that are being used for many diseases' treatment is derived from plants and natural sources. Pharmacologists, Medical Doctors, Scientists and pharmaceutical companies study the plants and herbs that are traditionally used for treatment of various diseases. After vigorous study they identify the particular molecule that has therapeutic properties. These molecules do undergo various modifications and mutations in laboratories. And then, it is mass produced in factories and systematically marketed.

For example, Digitalin which is a drug used to stimulate the heart. Well, Digitalin comes from an herb called foxglove. Another example is the effective anti-clotting agent called Coumarol, that comes from a herb sweet clover. Another one is Reserpine, which is one of the most popular tranquilizers. It is the first ever modern psychiatric drug. Most of the modern tranquilizers are derived from Reserpine. Reserpine comes from a herb named snakeroot. In India they used snakeroot for thousands of years to calm people down. Still another example is Quinine. It is very efficient in reducing fever, especially malarial fever. This drug comes from the Peruvian bark in South America. Another example is Asprin which was derived from white willow bark.

Let us see the herbs connection to Asthma. The first ever modern prescription medicine used to treat asthma is ephedrine. It is derived from the Chinese plant known as Ma Huang. Chinese have been using Ma Huang to treat breathing disorders, wheezing etc. for the past 2000 years. The molecule ephedrine was isolated from Ma Huang in 1940 and was widely prescribed since then. Cromolyn Sodium is another popular medicine used for the treatment of asthma. Cromolyn was derived from a plant knows as
Khellin (Ammi Visnaga) commonly found in Egypt. It was used as a muscle relaxant by Egyptians for many centuries. Dr. Roger Altouynan (the discoverer of Cromolyn molecule), an asthmatic, tried Khellin on himself and found it to be very beneficial. Today cromolyn sodium is one of the first lines of treatment for asthma. Cromolyn sodium has weaned great number of patients away from harmful corticosteroids. Cromolyn effectively prevents asthma attack before it occurs. Prescription medicines Codeine, atropine, hyoscyamine, digoxin, digitoxin, pilocarpine, and quinidine are all derived from plants. Asthma and Allergy are lifestyle diseases and herbs are extremely effective.

The goals of medicine no matters to which group it belongs, are the same i.e. welfare of patients. One can look towards a future of integrated medicine and hope that research in alternative medicine will help to cure asthma safe and effectively rather than managing.

\section{Conflict of interest statement}

We declare that we have no conflict of interest.

\section{References}

[1] Holgate ST, Polosa R. Treatment strategies for allergy and asthma. Nat Rev Immunol 2008; 8: 218-230.

[2] Donno DM, Bittesnich D, Chetta A, Olivieri D, Lopez-Vidriero MT. The effect of inflammation on mucociliary clearance in asthma. Chest 2000; 118(4): 1142-1149.

[3] Tattersfield AE, Knox AJ, Britton JR, Hall IP. Asthma. Lancet 2002 360: $1313-1322$.

[4] Masoli M, Fabian D, Holt S, Beasley R. The global burden of asthma: executive summary of the GINA Dissemination Committee report. Allergy 2004; 59: 469-478.

[5] Bousquet J, Bousquet PJ, Godard P, Daures JP. The public health implications of asthma. Bull World Health Organ 2005; 83:548-554.

[6] Braman SS. The global burden of asthma. Chest 2006; 130: 4S-12S.

[7] Greenberger PA. Therapy in management of rhinitis asthma complex. Allergy Asthma Proc 2003; 24: 403-407.

[8] Lyengar MA, Jambaiah KM and Rao GM. Studies on an antiasthma kada: A Proprietary Herbal Combination Part-I Clinical Study. Indian Drug 1994; 31(5): 183-186.

[9] Henricks PA, Nijkamp FP. Reactive oxygen species as mediators in asthma. Pulm. Pharmacol. Ther 2001; 14: 409-420.

[10] Slader CA, Reddel HK, Jenkins CR, Armour CL, Bosnic Anticevich SZ. Complementary and alternative medicine use in asthma: who is using what? Respirol 2006; 11: 373-387.

[11] Tripathi KD. Essentials of medical pharmacology. 4th ed. New Delhi,India: Jaypee brothers medical Publishers Ltd; 2001.

[12] Kumar D, Prasad DN, Parkash J, Bhatnagar SP, Kumar D. Antiasthmatic activity of ethanolic extract of Aerva lanata Linn. Pharmacologyonline 2009; 2: 1075-1081.

[13] Tote MV, Mahire NB, Jain AP, Bose S, Undale VR, Bhosale AV. Effect of Ageratum conyzoides Linn on clonidine and haloperidol 
induced catalepsy in mice. Pharmacologyonline 2009; 2: 186-194.

[14] Bhalke RD, Gosavi SA. Antistress and antiallergic effect of Argemone mexicana stem in asthma. Arch. Pharm Sci Res 2009; 1(1): 127-129.

[15] Akah PA, Ezike AC, Nwafor SV, Okoli CO, Enwerem NM. Evaluation of the anti-asthmatic property of Asystasia gangetica leaf extracts. J Ethnopharmacol 2003; 89: 25-36.

[16] Samiulla DS, Prashanth D, Amit A. Mast cell stabilising activity of Bacopa monnieri. Fitoterapia 2001; 72: 284-285.

[17] Nagore DH, Ghosh VK, Patil MJ. Evaluation of antiasthmatic activity of Cassia sophera Linn. Phcog Mag 2009; 5(19): 109-118.

[18] Aher AN, Pal SC, Patil UK, Yadav SK, Bhattacharya S. Evaluation of anthistaminic activity of Casuarina equisetifolia frost (Casuarinaceae). Pharmacologyonline 2009; 1: 1144-1149.

[19] Bhujbal SS, Kewatkar SM, Kumar D, Mudgade SC, Patil MJ. In vivo and in vitro antiasthmatic studies of Clerodendrum serratum Linn. Pharmacologyonline 2009; 2: 745-752.

[20] Matsuda H, Tomohiro N, Yasuko, Kubo M. Anti-allergic effects of cnidii monnieri fructus (Dried Fruits of Cnidium monnier) and Its major component, osthol. Bio Pharm Bull 2002; 25(6): 809-812.

[21] Okpo SO, Adeyemi OO. The anti-allergic effects of Crinum glaucum aqueous extract. Phytomedicine 2002; 9: 438-441.

[22] Venkatesh P, Mukherjee PK, Satheesh Kumar N, Neelesh K Nema, A Bandyopadhyay, Hiroyuki Fukui et al. Mast cell stabilization and antihistaminic potentials of Curculigo orchioides rhizomes. $J$ Ethnopharmacol 2009; 126: 434-436.

[23] Pandit P, Singh A, Bafna AR, Kadam PV, Patil MJ. Evaluation of antiasthmatic activity of Curculigo orchioides Gaertn. Rhizomes. Indian J Pharm Sci 2008; 70(4): 440-444.

[24] Patel MB, Panchal SJ, Patel JA. Antianaphylactic activity of alcoholic extract of Eclipta alba. J Young Pharm 2009; 1(3): 244-250.

[25] Youssouf MS, Kaiser P, Tahir M, Singh GD, Singh S, Sharma VK, et al. Anti-anaphylactic effect of Euphorbia hirta. Fitoterapia 2007; 78: $535-539$.

[26] Taur DJ, Nirmal SA, Patil RY. Effect of various extracts of Ficus bengalensis bark on clonidine and haloperidol-induced catalepsy in mice. Pharmacologyonline 2007; 3: 470-477.

[27] Taur DJ, Patil RY. Effect of bio-fractions isolated from Ficus bengalensis bark on clonidine induced catalepsy. J Pharmacy Res 2009; 2(11): 1676-1677.

[28] Akah PA, Gamaniel KS, Samson A, Wambebe CO. Evaluation of Nigerian traditional medicine: effects of Gakani, a herbal antiasthmatic drug. J Ethnopharmacol 1997; 55: 87-92

[29] Bhujbal SS, Kumar D, Deoda RS, Deore TK, Patil MJ. Antiasthmatic activity of roots of Hemidesmus indicus R. Br. Pharmacologyonline 2009; 1: 209-216.

[30] Luzia KAM Leal, Melina F Costa, Márcia Pitombeira, Viviane M Barroso, Edilberto R Silveira, Kirley M. Canuto, et al. Mechanisms underlying the relaxation induced by isokaempferide from Amburana cearensis in the guinea-pig isolated trachea. Life Sci 2006; 79: 98-104.

[31] Tewtrakul S, Subhadhirasakul S, Kummee S. Anti-allergic activity of compounds from Kaempferia parviflora. J Ethnopharmacol 2008; 116: 191-193.

[32] Mali RG, Mahajan SG, Mehta AA. Studies on bronchodilatory effect of Lepidium sativum against allergen induced bronchospasm in guinea pigs. Phcog Mag 2008; 4(15): 189-192.

[33] Satoshi Yamamura, Koichiro Ozawa, Kazuhiro Ohtani, Ryoji Kasai,
Kazuo Yamasak. Antihistaminic flavones and aliphatic glycosides from Mentha spicata. Phytochemistry 1998; 48(1): 131-136.

[34] Rakh MS, Raut DN, Chavan MJ, Chaudhari SR. Effect of various extracts of Momordica dioica pulp on clonidine and haloperidolinduced catalepsy in mice. Pharmacologyonline 2010; 1: 1-11.

[35] Pathan AA, Kasture SB, Mahalaxmi M. Residue of Mucuna pruriens potentiates haloperidol and clonidine-induced catalepsy in mice. Pharmacologyonline 2009; 3: 652-658.

[36] Patel KG, Rao NJ, Gajera VG, Bhatt PA, Patel KV, Gandhi TR. Antiallergic activity of stem bark of Myrica esculenta Buch. Ham. (Myricaceae). J Young Pharm 2010; 2(1): 74-78.

[37] Patel KG, Bhalodia PN, Patel AD, Patel KV, Gandhi. Evaluation of bronchodilator and anti-anaphylactic activity of Myrica sapida. Iranian Biomedical Journal 2008; 12(3): 191-196.

[38] Nirmal SA, Pal SC, Mandal SC. Antihistaminic activity of Nyctanthes arbortristis Bark. Pharmacologyonline 2009; 3: 924-928.

[39] Chandak R, Devdhe S, Changediya V. Evaluation of antihistaminic activity of aqueous extract of ripe olives of Oleaeuropea. J Pharm Res 2009; 2(3): 416-420.

[40] Ramanitrahasimbola D, Rakotondramanana DA, Rasoanaivo P, Randriantsoa A, Ratsimamanga S, Palazzino G, et al. Bronchodilator activity of Phymatodes scolopendria (Burm.) Ching and its bioactive constituent. J Ethnopharmacol 2005; 102: 400-407.

[41] Jawale NM, Shewale AB, Nerkar GS, Patil VR. Evalution of antihistaminic activity of leaves of Piper betel Linn. Pharmacologyonline 2009; 3: 966-977.

[42] Harish MS, Nagur M, Badami S. Antihistaminic and mast cell stabilizing activity of Striga orobanchioide. J Ethnopharmacol 2001; 76: 197-200.

[43] Dilkash NA, Tripathi T, Khan AA, Shahid M, Khan HM, Siddiqui $\mathrm{M}$, et al. Effects of histamine H1R-H4R - agonist on the airway epithelium of rabbits. Asian Pac J Trop Med 2010; 3(5): 367-370.

[44] Jung JY, Lee KY, Lee MY, Jung D, Cho ES, Son HY. Antioxidant and antiasthmatic effects of saucerneol D in a mouse model of airway inflammation. Int Immunopharmacol 2011.

[45] Boskabady MH, Mohsenpoor N, Takaloo L. Antiasthmatic effect of Nigella sativa in airways of asthmatic patients. Phytomedicine 2010; 17(10): 707-713.

[46] Jin M, Yang JH, Lee E, Lu Y, Kwon S, Son KH, et al. Antiasthmatic activity of luteolin-7-0-glucoside from Ailanthus altissima through the downregulation of T helper 2 cytokine expression and inhibition of prostaglandin E2 production in an ovalbumininduced asthma model. Biol Pharm Bull 2009; 32(9): 1500-1503.

[47] Pandit P, Singh A, Bafna AR, Kadam PV, Patil MJ. Evaluation of antiasthmatic activity of Curculigo orchioides Gaertn. rhizomes. Indian J Pharm Sci 2008; 70(4): 440-444.

[48] Agrawal B, Mehta A. Antiasthmatic activity of Moringa oleifera Lam: a clinical study. Indian J Pharmacol 2008; 40(1): 28-31.

[49] Li PB, Ma Y, Wang YG, Su WW. Experimental studies on antitussive, expectorant and antiasthmatic effects of extract from Citrus grandis var. tomentosa. Zhongguo Zhong Yao Za Zhi 2006; 31(16): 1350-1352.

[50] Mathew JE, Srinivasan KK, Dinakaran V, Joseph A. Mast cell stabilizing effects of Sphaeranthus indicus. J Ethnopharmacol 2009; 122: 394-396.

[51] Savali AS, Biradar PR, Jirankali MC. Antianaphylactic and mast cell stabilization activity of Cynodon dactylon. Int J Pharm and Pharm Sci 2010; 2(2): 69-73. 